\title{
Effect of Marker Aided Pyramiding of Anthracnose and Pythium Root Rot Resistance Genes on Plant Agronomic Characters among Advanced Common Bean Genotypes
}

\author{
M. Kiryowa ${ }^{1}$, S. T. Nkalubo ${ }^{2}$, C. Mukankusi ${ }^{3}$, H. Talwana ${ }^{1}$, P. Gibson ${ }^{4} \&$ P. Tukamuhabwa ${ }^{1}$ \\ 1 Department of Agricultural Production, College of Agricultural \& Environmental Sciences, Makerere \\ University, Kampala, Uganda \\ ${ }^{2}$ National Crops Resources Research Institute (NaCRRI), NARO, Kampala, Uganda \\ ${ }^{3}$ Centro Internacional de Agricultura Tropical (CIAT), Kampala, Uganda \\ ${ }^{4}$ Department of Plants, Soils, Agricultural Systems, Southern Illinois University, Carbondale, IL, USA \\ Correspondence: M. Kiryowa, Department of Agricultural Production, College of Agricultural \& Environmental \\ Sciences, Makerere University, P.O. Box 7062, Kampala, Uganda. Tel: 256-712-961-309. E-mail: \\ m.kiryowa@gmail.com
}

Received: April 16, 2014 Accepted: November 24, 2014 Online Published: February 15, 2015

doi:10.5539/jas.v7n3p98 URL: http://dx.doi.org/10.5539/jas.v7n3p98

\begin{abstract}
One of the factors that accounts for the low yields in common bean is the simultaneous occurrence of diseases on the common bean crop. Bean root rots and anthracnose are the most important common bean diseases that simultaneously occur on the bean crop in Uganda. Moreover, Colletotrichum lindemuthianum, the pathogen that causes bean anthracnose, possesses a high genetic variability which makes it easily break down single gene resistance. Pyramiding resistance genes for both diseases in commercial varieties would ensure reduction of yield losses resulting from the two diseases. However, the effect of marker assisted gene pyramiding on plant agronomic characters is not well understood. Three-way crosses were made to pyramid three anthracnose and one Pythium root rot resistance genes in four susceptible market class varieties. Sequence characterized amplified regions (SCAR) markers were used to facilitate the pyramiding scheme. Correlation analysis and Path coefficient analysis were used to assess the association between number of pyramided genes and different plant agronomic characters. Number of pyramided genes was negatively correlated with number of pods per plant $(-0.32)$, number of seeds per plant $(-0.25)$, number of seeds per pod $(-0.18)$, pod length $(-0.17)$, days to $50 \%$ flowering (-0.09) and 100-seed weight (-0.02). Path coefficient analysis showed that number of pyramided genes, plant height, days to $50 \%$ flowering, number of seeds per pod and number of pods per plant had negative direct effects on seed weight per plant. Number of seeds per plant had the highest positive direct effects $(0.98)$ followed by 100 -seed weight $(0.28)$ while days to maturity had the least positive direct effect $(0.03)$ on seed weight per plant. Only number of seeds per plant had its correlation coefficient $(0.94)$ almost equal to the direct path coefficient $(0.97)$. Number of pyramided genes had significant $(P<0.05)$ negative indirect effect on seed weight per plant only through number of seeds per plant $(-0.25)$. Therefore, pyramiding higher numbers of resistance genes may cause a grain yield reduction via number of seeds per plant. Therefore, it is important for breeders to simultaneously select for number of pyramided genes with number of seeds per plant and other highly associated traits.
\end{abstract}

Keywords: Phaseolus vulgaris, correlation analysis, path analysis, pyramided genes, grain yield

\section{Introduction}

The common bean, Phaseolus vulgaris (L.) is the most important legume crop in Uganda occupying an important niche in the Agricultural sector and farm household economy (Opio et al., 2001). Common beans provide up to $45 \%$ of the total human dietary requirements of proteins (Mauyo et al., 2007) for resource poor farmers and in addition provide appreciable levels of $\mathrm{B}$ vitamins, iron and Magnesium among other micro-nutrients. Common bean production in Uganda is, however, greatly constrained by the simultaneous occurrence of bean anthracnose caused by Colletotrichum lindemuthianum (Sacc. et. Magn) Lams. Scrib., and bean root rots. Colletotrichum lindmeuthianum is a highly variable pathogen both pathogenically and genetically 
(Mahuku \& Riascos, 2004; Kelly \& Vallejo, 2004) consequently making single gene resistance short lived and highly vulnerable to dynamic and diverse plant pathogen populations. Bean anthracnose can cause yield losses of upto $44 \%$ when susceptible varieties are used (Nkalubo et al., 2007). Root rots on the other hand usually occur as a complex of many pathogens, with Pythium spp. being the predominant pathogen in the complex (Mukalazi, 2004), Root rots are capable of causing yield losses of up to $100 \%$ on susceptible varieties (Tusiime, 2003; Mukankusi, 2010).

Chemical control of the two diseases is not widely adopted by farmers in Uganda because it raises production costs and is not eco-friendly. Therefore, the use of resistant cultivars offers farmers an efficient, safe and inexpensive alternative for managing the two diseases. With the help of molecular markers, it is possible to combine both bean anthracnose and Pythium spp. resistance genes in a common susceptible background. The use of molecular markers to select desirable plants eliminates extensive phenotyping thus reducing the breeding duration (Ye and Smith, 2008). Marker assisted gene pyramiding has been successfully used to pyramid resistance genes to create broad and durable resistance in different crops (Ferreira et al., 2012; Ragagnin et al., 2009; Shi et al., 2008; Bates et al., 2005; Liu et al., 2000). However, its effect on plant agronomic characters is not well elucidated.

Generally, direct selection for yield may not be effective as it is a complex trait and depends upon the component traits. Therefore, understanding the association of characters is crucial in developing an efficient breeding program that aims at developing high yielding and stable varieties. More than one trait should be considered in a common bean breeding program using pure lines. In addition to grain yield, other traits such as 100 -seed weight, pods per plant, disease resistance, seeds per pod, pod length, yield per plant should be observed and measured to complement the objectives of the program (Gonzalves et al., 2003). Correlation coefficients are used to show relationships among independent characteristics and describe relationships in a simple manner (Yucel et al., 2006). An analysis of correlation between yield and yield components is essential in determining selection criteria. The estimated correlation measured from the association among the character enables the breeder to understand the changes that occur in a determined trait in function of the selection practiced on another correlated trait (Gonzalves et al., 2003). However, the quantification and interpretation of the magnitude of a correlation can result in errors when indirect selection strategy is used based on the effect of a third trait or of a group of other traits on them (Gonzalves, 2003). Path coefficient analysis permits the partitioning of the correlation coefficients into direct and indirect effects of a set of independent variables on the dependent variable (Guler et al., 2001; Manoel et al., 2003) and, therefore, plays an important role in determining the degree of relationship between yield and its components (Ciftci et al., 2004). There is need, therefore, to determine relationship between number of pyramided genes inherited and grain yield, and its component characters. The purpose of this study was to determine degree of association between number of pyramided genes and yield characters.

\section{Materials and Methods}

A cascading pedigree gene pyramiding scheme was used to cross three donor parents namely G2333 (anthracnose resistance genes $\mathrm{Co}-4^{2}, \mathrm{Co}-5$ ), PI207262 (anthracnose resistance genes $\mathrm{Co}-4^{3} \& \mathrm{Co}-9$ ) and RWR719 (Pythium resistance gene) with four susceptible commercial varieties K132, NABE 4, NABE 13 and NABE 14 (Figure 1). SCAR markers were used in marker assisted selection with SAS13 tagging Co- $4^{2} \& \mathrm{Co}-4^{3}$ alleles, SBB14 tagging $\mathrm{Co}^{2} 4^{2}$ allele, SAB3 tagging $\mathrm{Co}-5$ allele, SB12 tagging $C o-9$ allele and $P Y A A 19_{800}$ tagging the Pythium resistance allele. Plants with different numbers of genes ranging from 0 to 4 were selected using markers and the genes fixed through selfing individual plants and further MAS up to F4 generation. F5 and F6 seeds were used for this experiment. The experiment was conducted during the second season of 2012 with 45 families and the first season of 2013 with 67 families at the National Agricultural Research Laboratories (NARL), Kawanda, located $0^{\circ} 24^{\prime} 38.15^{\prime \prime} \mathrm{N}$ and $32^{\circ} 32^{\prime} 14.06^{\prime \prime} \mathrm{E}$ and elevated at 1147 meters above sea level. A nested randomized complete block design (RCBD) with three replicates was used. Single row plots of $1.5 \mathrm{~m}$ length were used with a $50 \mathrm{~cm}$ between row and $15 \mathrm{~cm}$ within row spacing. 




Figure 1. Cascading pedigree gene pyramiding scheme. H refers to hybrid created by the cross

Data was collected on plant vigor at two weeks after planting $(1-5$ where $1=$ poor vigor and $5=$ high vigor $)$, number of pods per plant, number of seeds per pod, pod length $(\mathrm{cm})$, number of seeds per plant, seed weight per plant (gm), 100-seed weight (gm), plants at harvest per family, days to $50 \%$ flowering, days to maturity and number of pyramided genes.

The degree of association of different characters was done through correlation analysis with correlation coefficients calculated using the formula by Weher and Moorthy (1952):

$$
r_{x y}=\operatorname{Cov} X Y / \sqrt{\sigma_{p}^{2} x \cdot \sigma_{g}^{2} y}
$$

Where; $\mathrm{r}_{x y}=$ Correlation between characters $x$ and $y$; $\operatorname{Cov} X Y=$ Covariance between characters $x$ and $y \sigma_{\mathrm{p}}{ }^{2} x . \sigma_{\mathrm{g}}{ }^{2} y$ $=$ Phenotypic variance of characters $x$ and $y$ respectively.

Path analysis was done according to the method described by Akintunde (2012). Path coefficients were obtained by solving the simultaneous equations which express the basic relationships between correlations and path coefficients as follows:

$$
\begin{aligned}
& r_{x 1 . y}=P_{x 1 . y}+r_{x 1 . x 2} P_{x 2 . y}+r_{x 1 . x 3} P_{x 3 . y}+r_{x 1 . x 4} P_{x 4 . y}+r_{x 1 . x 5} P_{x 5 . y}+r_{x 1 . x 6} P_{x 6 . y}+r_{x 1 . x 7} P_{x 7 . y}+r_{x 1 . x 8} P_{x 8 . y}+r_{x 1 . x 9 P x 9 . y}+r_{x 1 . x 10} P_{x 10 . y} \\
& r_{x 2 . y}=r_{x 2 . x 1} P_{x 1 . y}+P_{x 2 . y}+r_{x 2 . x 3} P_{x 3 . y}+r_{x 2 . x 4} P_{x 4 . y}+r_{x 2 . x 5} P_{x 5 . y}+r_{x 2 . x 6} P_{x 6 . y}+r_{x 2 . x 7} P_{x 7 . y}+r_{x 2 . x 8} P_{x 8 . y}+r_{x 2 . x 9} P_{x 9 . y}+r_{x 2 . x 10} P_{x 10 . y} \\
& \text {... } \\
& r_{x 10 . y}=r_{x 10 . x 1} P_{x 1 . y}+r_{x 10 . x 2} P_{x 2 . y}+r_{x 10 . x 3} P_{x 3 . y}+r_{x 10 . x 4} P_{x 4 . y}+r_{x 10 . x 5} P_{x 5 . y}+r_{x 10 . x 6} P_{x 6 . y}+r_{x 10 . x 7} P_{x 7 . y}+r_{x 10 . x 8} P_{x 8 . y}+r_{x 10 . x 9} P_{x 9 . y} \\
& +P_{x l 0 . y}
\end{aligned}
$$

Where; $r_{x 1 . y}$ to $r_{x 10 . y}$ denotes the correlation coefficients between independent characters $x 1$ to $x 10$ and the dependent character $y ; r_{x I . x 2}$ to $r_{x 10 . x 9}$ denotes the correlation coefficients between all possible combinations of independent characters; $P_{x 1 . y}$ to $P_{x 10 . y}$ denotes the direct effects of characters $x l$ to $x 10$.

\section{Results and Discussion}

\subsection{Correlation Analysis}

Table 1 shows the correlation matrix of 11 plant growth and yield characters of beans. Number of seeds per plant (0.92), number of pods per plant (0.82), pod length (0.56), plant vigor (0.56) and 100-seed weight $(0.42)$ respectively exhibited the highest positive correlation with seed weight per plant implying the dependence of plant yield on these characters. Number of seeds per pod (0.46), plant height $(0.45)$ and days to maturity $(0.17)$ were also positively correlated with seed weight per plant but with lower correlation coefficients. These results 
are consistent with the findings of Cokkizgin et al. 2001, who found seed yield to be significantly correlated with all yield traits except plant height and 100-seed weight. Number of pyramided genes exhibited negative correlation $(-0.17)$ with seed weight per plant suggesting a slight yield penalty for pyramiding.

Table 1. Correlation matrix for seed weight per plant and different plant growth and yield characters

\begin{tabular}{|c|c|c|c|c|c|c|c|c|c|c|c|}
\hline Variables & $S W P$ & $N P G$ & $P V$ & $P H$ & $D F$ & $D M$ & $N S P$ & $P L$ & $N P P$ & $N S P T$ & $100 S W$ \\
\hline$S W P$ & 1.00 & & & & & & & & & & \\
\hline$N P G$ & $-0.17 * * *$ & 1.00 & & & & & & & & & \\
\hline$P V$ & $0.56^{* * *}$ & $-0.02 \mathrm{~ns}$ & 1.00 & & & & & & & & \\
\hline$P H$ & $0.45^{* * *}$ & 0.00 & $0.33 * * *$ & 1.00 & & & & & & & \\
\hline$D F$ & $-0.03 n s$ & $-0.09 \mathrm{~ns}$ & $-0.24 * *$ & $0.30 * *$ & 1.00 & & & & & & \\
\hline$D M$ & $0.17 \mathrm{~ns}$ & $0.08 \mathrm{~ns}$ & $-0.03 n s$ & $0.39 * * *$ & $0.63 * * *$ & 1.00 & & & & & \\
\hline$N S P$ & $0.46^{* * *}$ & $-0.18 \mathrm{~ns}$ & $0.25 * *$ & $0.56 * * *$ & $0.25^{* *}$ & $0.18 \mathrm{~ns}$ & 1.00 & & & & \\
\hline$P L$ & $0.56^{* * *}$ & $-0.17 \mathrm{~ns}$ & $0.36 * * *$ & $0.50 * * *$ & $0.13 \mathrm{~ns}$ & $0.11 \mathrm{~ns}$ & $0.86^{* * *}$ & 1.00 & & & \\
\hline$N P P$ & $0.82 * * *$ & $-0.24 * *$ & $0.39 * * *$ & $0.40 * * *$ & $-0.05 \mathrm{~ns}$ & $0.15 \mathrm{~ns}$ & $0.31 * *$ & 0.45 & 1.00 & & \\
\hline$N S P T$ & $0.92 * * *$ & $-0.19 *$ & $0.39 * * *$ & $0.49 * * *$ & $0.07 \mathrm{~ns}$ & $0.25^{* *}$ & $0.52 * * *$ & $0.56 * * *$ & $0.85 * * *$ & 1.00 & \\
\hline $100 S W$ & $0.42 * * *$ & $-0.02 \mathrm{~ns}$ & $0.42 * * *$ & $0.12 \mathrm{~ns}$ & $-0.19^{*}$ & $-0.12 n s$ & $0.01 \mathrm{~ns}$ & $0.23 *$ & $0.03 \mathrm{~ns}$ & $-0.09 \mathrm{~ns}$ & 1.00 \\
\hline
\end{tabular}

Note. ${ }^{* * *}$ Highly significant $(P<0.01),{ }^{* *}$ Significant $(P<0.05),{ }^{*}$ Significant $(P<0.1) . \mathrm{ns}=$ not significant. $S W P=$ seed weight per plant, $N P G=$ number of pyramided genes, $P V=$ plant vigor, $P H=$ plant height, $D F=$ days to $50 \%$ flowering, $D M=$ days to maturity, $N S P=$ number of seeds per pod, $P L=$ pod length, $N P P=$ number of pods per plant, $N S P T=$ number of seeds per plant and $100 S W=100$-seed weight.

Additionally, Number of pyramided genes negatively correlated with number of pods per plant $(-0.24)$, number of seeds per plant (-0.19), number of seeds per pod (-0.18), pod length $(-0.17)$, days to $50 \%$ flowering $(-0.09)$ and 100-seed weight (-0.02). This implies that pyramiding for higher numbers of resistance genes in a common background is most likely to directly affect plant yield through number of pods per plant followed by number of seeds per plant, number of seeds per pod and pod length.

Yield determining characters had a high positive correlation each other. For instance, number of seeds per pod was highly correlated with pod length $(0.86)$. Number of pods per plant was highly correlated with number of seeds per plant $(0.85)$ and number of seeds per plant $(0.52)$. Plant vigor was highly correlated with 100 -seed weight (0.42).

Results are consistent with findings of Verma et al. (2004), Dursun (2007) and Cokkizgin et al. (2013) who reported that pod length showed positive and significant correlation with number of seeds per pod, number of pods per plant and number of seeds per plant. They further revealed that number of seeds per pod had a positive and significant relationship with number of seeds per plant and seed yield per plant and that number of pods per plant had a strong positive relationship with number of seeds per plant. Therefore, to ensure high yielding pyramided lines, it would be important for breeders to select for these characters simultaneously with number of pyramided lines. Plant height also had a high positive correlation with yield characters such as number of seeds per pod (0.56), pod length (0.50), number of seeds per plant (0.49) and number of pods per plant $(0.40)$. This implies that simultaneous selection for taller plants especially climbers with a higher number of pyramided genes would contribute to yield increase among pyramided lines.

\subsection{Path Coefficient Analysis}

Path coefficient analysis provides an effective means of separating direct and indirect cause of association and permits critical examination of the specific forces acting to produce a given correlation and measures the relative importance of each causal factor (Singh et al., 2013). Table 2 gives estimates of direct and indirect path coefficients using seed weight per plant as the response variable. Number of seeds per plant $(0.98)$, pod length $(0.06)$, days to maturity $(0.03), 100$-seed weight $(0.28)$ and plant vigor $(0.08)$ had positive direct effects on seed weight per plant, but only effects of number of seeds per plant and 100 -seed weight were significant $(P<0.01 ; P$ $<0.5$ respectively). Number of pyramided genes, plant height, days to $50 \%$ flowering, number of seeds per pod 
and number of pods per plant had negative direct effects but non of them was significant $(P<0.01 ; P<0.05$ and $P=0.1)$. Only number of seeds per plant had its correlation coefficient $(0.94)$ almost equal to the direct path coefficient (0.98) implying that only number of seeds per plant correlated with seed weight per plant in a true relationship.

All characters except days to $50 \%$ flowering had significant $(P<0.01, P<0.05)$ positive indirect effects on seed weight per plant only through number of seeds per plant, with number of pods per plant having the most significant $(P<0.01)$ effect $(0.88)$, followed by pod length $(0.55)$, number of seeds per pod $(0.51)$, plant height $(0.48)$, plant vigor $(0.37), 100$-seed weight $(0.27)$ and days to maturity $(0.24)$. Therefore, grain yield can best be improved through direct selection for number of seeds per plant and by indirectly selecting for number of pods per plant, pod length, number of seeds per pod, plant height and plant vigor respectively. Results are consistent with findings of Tunturk et al. (2004), Peksen and Gulumser (2005), and Ahmadzadeh et al. (2012).

Of all characters considered in the study, only number of pyramided genes had a significant $(P<0.05)$ negative indirect effect on seed weight per plant through number of seeds per plant $(-0.25)$. This implies that molecular marker-based gene pyramiding for higher numbers of resistance genes could indirectly affect plant grain yield by causing a reduction in number of seeds per plant.

Table 2. Direct and indirect path coefficients for seed weight per plant

\begin{tabular}{llllllllllll}
\hline Variables & $N P G$ & $P V$ & $P H$ & $D F$ & $D M$ & $N S P$ & $P L$ & $N P P$ & $N S P L T$ & $100 S W$ & $S \boldsymbol{W}(\boldsymbol{r})$ \\
\hline$N P G$ & $\underline{\mathbf{- 0 . 0 1 2}}$ & 0.013 & -0.000 & 0.004 & 0.002 & 0.012 & -0.011 & 0.050 & $-0.246^{* *}$ & -0.006 & $\mathbf{- 0 . 1 9 4 *}$ \\
$P V$ & -0.002 & $\underline{\mathbf{0 . 0 8 2}}$ & -0.006 & 0.010 & -0.001 & -0.017 & 0.022 & -0.052 & $0.371^{* * *}$ & 0.143 & $\mathbf{0 . 5 4 9 * * *}$ \\
$P H$ & -0.000 & 0.027 & $\underline{\mathbf{- 0 . 0 1 8}}$ & -0.012 & 0.010 & -0.038 & 0.031 & -0.063 & $0.478^{* * *}$ & 0.033 & $\mathbf{0 . 4 4 7} * * *$ \\
$D F$ & 0.001 & -0.020 & -0.005 & $\underline{\mathbf{- 0 . 0 4 0}}$ & 0.016 & -0.017 & 0.008 & 0.008 & 0.070 & -0.054 & $\mathbf{- 0 . 0 3 4}$ \\
$D M$ & -0.001 & -0.002 & -0.007 & -0.025 & $\underline{\mathbf{0 . 0 2 5}}$ & -0.012 & 0.007 & -0.024 & $0.240^{* *}$ & -0.034 & $\mathbf{0 . 1 6 5}$ \\
$N S P$ & 0.002 & 0.021 & -0.010 & -0.010 & 0.005 & $\underline{\mathbf{- 0 . 0 6 7}}$ & 0.053 & -0.048 & $0.511^{* * *}$ & 0.002 & $\mathbf{0 . 4 5 6 * * *}$ \\
$P L$ & 0.002 & 0.030 & -0.009 & -0.005 & 0.003 & -0.058 & $\underline{\mathbf{0 . 0 6 1}}$ & -0.070 & $0.548^{* * *}$ & 0.063 & $\mathbf{0 . 5 6 5 * * *}$ \\
$N P P$ & 0.002 & 0.026 & -0.007 & 0.002 & 0.004 & -0.021 & 0.027 & $\underline{\mathbf{- 0 . 1 5 7}}$ & $0.882^{* * *}$ & 0.105 & $\mathbf{0 . 8 6 7 * * *}$ \\
NSPLT & 0.003 & 0.031 & -0.009 & -0.003 & 0.006 & -0.035 & 0.035 & -0.142 & $\underline{\mathbf{0 . 9 7 5} * * *}$ & 0.076 & $\mathbf{0 . 9 3 7 * * *}$ \\
100SW & 0.000 & 0.042 & -0.002 & 0.008 & -0.003 & -0.000 & 0.014 & -0.060 & $0.268^{* *}$ & $\underline{\mathbf{0 . 2 7 6} * *}$ & $\mathbf{0 . 5 4 4 * * *}$ \\
\hline
\end{tabular}

Note. *** Highly significant $(P<0.01),{ }^{* *}$ Significant $(P<0.05),{ }^{*}$ Significant $(P<0.1) . S W P(r)=$ seed weight per plant, $N P G=$ number of pyramided genes, $P V=$ plant vigor, $P H=$ plant height, $D F=$ days to $50 \%$ flowering, $D M=$ days to maturity, $N S P=$ number of seeds per pod, $P L=$ pod length, $N P P=$ number of pods per plant, $N S P L T=$ number of seeds per plant and $100 S W=100$-seed weight. Residual $=1-\sqrt{ } \mathrm{R}^{2}=0.0519$. The sum of direct and indirect path coefficients appears in bold in the last column of the table to the right. Direct path coefficients appear diagonally in bold and underlined. The rest of the coefficients are indirect coefficients.

\section{Conclusion}

The study demonstrated that selection for higher numbers of pyramided genes using molecular markers may indirectly cause a yield reduction via number of seeds per plant. To remedy or lessen the potential yield loss, breeders undertaking marker assisted selection in gene pyramiding programs targeting higher number of resistance genes should simultaneously select for number of seeds per plant, number of pods per plant, pod length, plant vigor, 100 seed weight, number of seeds per pod and plant height.

\section{Acknowledgements}

The study was funded by the Uganda National Council for Science and Technology (MSI project), International Center for Agriculture in the Tropics (CIAT/PABRA-Uganda) and the National Agricultural Research Organization (NARO-ATAAS project).

\section{References}

Ahmadzadeh, A. R., Alizadeh, B., Shahryar, H. A., \& Narimani-Rad, M. (2012). Path analysis of the relationships between grain yield and some morphological characters in spring safflower (Carthamus 
tinctorius) under normal irrigation and drought stress condition. Journal of Medicinal Plants Research, 6(7), 1268-1271. http://dx.doi.org/10.5897/JMPR11.1327

Akintunde, A. (2012). Path analysis step by step using Excel. Journal of Technical Science and Technologies, $1(1), 9-15$.

Bates, S. L., Zhao, J., Roush, R. T., \& Shelton, A. M. (2005). Insect resistance management in GM crops: past, present and future. Nat Biotech, 23, 57-62. http://dx.doi.org/10.1038/nbt1056

Ciftci, V., Togay, N., Togay, Y., \& Dogan, Y. (2004). Determining relationships among yield and some yield components using path coefficient analysis in chickpea (Cicer arietinum L.). Asian Journal of Plant Sciences, 3(5), 632-635. http://dx.doi.org/10.3923/ajps.2004.632.635

Cokkizgin, A., Colkese, M., Idikut, L., Ozsisli, \& Girgel. (2013). Determination of relationships between yield components in bean by using path coefficient analysis. Greener Journal of Agricultural Sciences, 3(2), 85-89.

Dursun, A. (2007). Variability, heritability and correlation studies in bean (Phaseolus vulgaris L.) genotypes. World Journal of Agricultural Sciences, 3(1), 12-16.

Ferreira, J. J., Campa, A., Perez-Vega, E., Rodriguez-Suarez, C., \& Giraldez, R. (2012). Introgression and pyramiding into common bean market fabada of genes conferring resistance to anthracnose. Theoretical and Applied Genetics, 124, 777-788. http://dx.doi.org/10.1007/s00122-011-1746-x

Gonzalves, M. C. (2003). Correlation and path analysis of common bean grain yield and its primary components. Crop Breeding and Applied Biotechnology, 3(3), 217-222.

Guler, M., Adak, M. S., \& Ulukan, H. (2001). Determining relationships among yield and some yield components using path coefficient analysis in chickpea (Cicer arietinum L). European Journal of Agronomy, 14,161-166. http://dx.doi.org/10.1016/S1161-0301(00)00086-1

Kelly, J. D., \& Vallejo, V. A. (2004). A comprehensive review of the major genes conditioning resistance to anthracnose in common bean. HortScience, 39, 1196-1207.

Liu, J., Liu, D., Tao, W., Li, W., Wang, S., Chen, P., ... Gao, D. (2000). Molecular marker-facilitated pyramiding of different genes for powdery mildew resistance in wheat. Plant Breeding, 119, 21-24. http://dx.doi.org/10.1046/j.1439-0523.2000.00431.x

Mahuku, S. G., \& Riascos, J. J. (2004). Virulence and molecular diversity within Colletotrichum lindemuthianum isolates from Andean and Mesoamerican bean varieties and regions. European Journal of Plant Pathology, 110, 253-263. http://dx.doi.org/10.1023/B:EJPP.0000019795.18984.74

Mauyo, L. W., Okalebo, J. R., Kirkby, R. A., Buruchara, R., Ugen, M., \& Musebe, R. O. (2007). Legal and institutional constraints to Kenya-Uganda cross-boarder bean marketing. African Journal of Agricultural Research, 2(11), 578-582.

Mukalazi, J. (2004). Pathogen variation and quantification of Pythium species in bean fields in Uganda (PhD Thesis). Makerere University, Kampala.

Mukankusi, M. C., Melis, R., Derera, J., Laing, M., \& Buruchara, A. R. (2010). Identification of sources of resistance to Fusarium root rot among selected common bean lines in Uganda. Journal of Animal and Plant Sciences, 7(3), 876-891.

Nkalubo, S., Melis, R., Laing, M. D., \& Opio, F. (2007). Yield loss associated with anthracnose disease on Ugandan market-class dry bean cultivars. African Crop Science Conference Proceedings (Vol. 8. pp. 869-874).

Opio, F., Kyamanywa, M. A., David, S., \& Mugisha-Mutetikka, M. (2001). In J. Mukiibi (Ed.), Agriculture in Uganda (Vol. 11). National Agriculture Research Organization (NARO).

Peksen, E., \& Gulumser, A. (2005). Relationships between seed yield and yield components and path analysis in some common bean (Phaseolus vulgaris L.) genotypes. Journal of Faculty of Agriculture. OMU, 20(3), 82-87.

Ragagnin, V. A., De Souza, T. L. P. O., Sanglard, D. A., Arruda, K. M. A., Costa, M. R., Alzate-Marin, A. L., ... De Barrios, E. G. (2009). Plant Breeding, $128, \quad$ 156-163. http://dx.doi.org/10.1111/j.1439-0523.2008.01549.x

Shi, A., Chen, P., Li, D., Zheng, C., Zhang, B., \& Hou, A. (2008). Pyramiding multiple genes for resistance to 
soybean mosaic virus in soybean using molecular markers. Molecular Breeding. http://dx.doi.org/10.1007/s11032-008-9219-x.

Singh, A., Avtar, R., Singh, D., Sangwan, O., \& Balyan, P. (2013). Genetic variability, character association and path analysis for seed yield and component traits under two environments in Indian mustard. Journal of oilseed Brassica, 4(1), 43-48.

Tuncturk, M., \& Ciftici, V. (2004). Relationship among traits using correlation and path coefficient analysis in safflower. Asian J. Plant Sci., 3, 683-686. http://dx.doi.org/10.3923/ajps.2004.683.686

Tusiime, G. (2003). Variation and detection of Fusarium solani f.sp. phaseoli and quantification of soil inoculum in common bean fields ( $\mathrm{PhD}$ Thesis). Makerere University, Kampala, Uganda.

Verma, A. K., Matho, R. N., \& Bhattacharya, A. (2004). Path analysis in lentil (Lens culinaris Medik). Journal of Research, Birsa Agricultural University, 16(1), 135-138.

Weher, C. R., \& Moorthy, B. R. (1952). Heritable and non-heritable relationships and variability of oil content and agronomic characters in the F2 generation of soybean crosses. Agronomy Journal, 44, 202-209. http://dx.doi.org/10.2134/agronj1952.00021962004400040010x

Ye, G., \& Smith, F. K. (2008). Marker-assisted gene pyramiding for inbred line development: basic principles and practical guidelines. International Journal of Plant Breeding, 2(1), 1-10.

Yucel, O. D., Anlarsal, A. E., \& Yucel, C. (2006). Genetic variability, correlation and path analysis of yield, and yield components in chickpea (Cicer arietinum L.). Turkish Journal of Agriculture and Forestry, 30, 183-188.

\section{Copyrights}

Copyright for this article is retained by the author(s), with first publication rights granted to the journal.

This is an open-access article distributed under the terms and conditions of the Creative Commons Attribution license (http://creativecommons.org/licenses/by/3.0/). 